\title{
Rumen Digestion and Nutritional Efficiency of Dairy Heifers Limit-Fed a High Forage Ration to Four Levels of Dry Matter Intake ${ }^{1}$
}

\author{
G. I. Zanton and A. J. Heinrichs ${ }^{2}$ \\ Department of Dairy and Animal Science, The Pennsylvania State University, University Park 16802
}

\begin{abstract}
Eight rumen-cannulated Holstein dairy heifers [beginning body weight (BW) $340( \pm 5) \mathrm{kg}$ and age $14.5( \pm 1)$ mo] were fed a high forage diet at 4 levels of intake. Diets were composed of grass silage, grass hay, and corn silage as the forage components and offered at 1.25 , $1.50,1.75$, and $2.00 \%$ of BW to heifers in a replicated Latin square design. Diets were incubated in situ in heifers receiving all 4 levels of feed. Blood and rumen were sampled at 2 -h intervals for $24 \mathrm{~h}$, rumen contents were emptied, and total fecal and urine collection was made. Dietary intake increased in proportion to feed offered until dry matter intake (DMI) was $1.92 \%$ BW, after which a statistically determined plateau was evident due to greater refusals when feed was offered at $2.00 \%$ BW. In situ degradation of feed was not affected by intake level, which, combined with the greater turnover rate of rumen contents, leads to the inference that rate of passage was increased with increasing intake. Rumen $\mathrm{pH}$ decreased and rumen volatile fatty acid concentration and microbial protein flow to the small intestine (estimated using urinary purine derivative excretion) increased as intake increased. Manure excretion increased as DMI increased at a rate 2.54 times greater than increases in DMI; this increase was entirely due to greater excretion of wet feces because urine excretion did not change with intake level. Nitrogen digestibility decreased and $\mathrm{N}$ retention increased linearly as the level of feed offered increased. Efficiency of $\mathrm{N}$ retention was minimized when feed was offered at $1.25 \% \mathrm{BW}$; all levels of feed offered above this level resulted in equivalent efficiencies. From the results of this experiment it can be concluded that when dairy heifers are limit-fed a high forage diet, the efficiency of nutrient utilization is increased as intake decreases, but reducing DMI below 1.50\% BW reduced efficiency.
\end{abstract}

\footnotetext{
Received March 29, 2008.

Accepted May 12, 2008.

${ }^{1}$ This research was a component of NC-1042; Management Systems to Improve the Economic and Environmental Sustainability of Dairy Enterprises.

${ }^{2}$ Corresponding author: ajh@psu.edu
}

Key words: digestibility, dry matter intake, heifer, rumen digestion

\section{INTRODUCTION}

Feedstuffs contribute substantially to the costs associated with rearing the dairy heifer from birth to calving. Controlling the impact of this contribution becomes increasingly important as the heifer approaches maturity because consumed nutrients are disproportionately partitioned to maintenance functions as opposed to growth. Research relating growth rates of prepubertal dairy heifers and first lactation milk production have emphasized that milk production may be optimized at submaximal levels of ADG (Zanton and Heinrichs, 2005). Although rapid postpubertal ADG does not significantly reduce first lactation milk production, the tendency for reduced milk production and the potential peripartum complications due to inappropriate BW and body composition at first calving recommend against uncontrolled ADG for this period as well (Hoffman et al., 1996). For the preceding reasons, ADG throughout the rearing phase should be sustained at a level rapid enough to meet age at first calving goals, but not so rapid as to create the potential for reduced first lactation milk production or periparturient metabolic disorders. With the growing dairy heifer, controlled ADG is frequently accomplished by reducing diet digestibility, utilizing high fiber components in an effort to reduce voluntary DMI.

However, reducing dietary digestibility by the inclusion of high fiber components may contribute to reduced feed efficiency associated with raising dairy heifers. Energy costs associated with the gastrointestinal tract and liver have each been estimated to contribute up to or exceeding $25 \%$ of whole body oxygen consumption (Reynolds et al., 1991), indicating that an opportunity may exist to reduce these tissues' contribution toward nutritional inefficiency. In that experiment (Reynolds et al., 1991), the level of oxygen consumed by the total splanchnic tissues for beef heifers fed a low level of intake was $\sim 61 \%$ of oxygen consumed by heifers fed a high level of intake. McLeod and Baldwin (2000) indicate that differences in splanchnic tissue oxygen 
Table 1. Ingredients and composition of ration limit-fed to dairy heifers at 4 levels of DMI

\begin{tabular}{|c|c|c|c|c|c|c|c|c|c|}
\hline Ingredient & $\%$ of ration DM & DM, \% & \multicolumn{6}{|c|}{$\% \mathrm{DM}$} & $\mathrm{SP},{ }^{1} \% \mathrm{CF}$ \\
\hline Grass silage & 34.93 & 36.61 & 92.44 & 63.05 & 41.29 & 12.65 & 3.30 & 7.69 & 55.80 \\
\hline Corn silage & 23.70 & 36.30 & 96.48 & 39.00 & 22.86 & 7.20 & 3.13 & 36.51 & 61.84 \\
\hline Cracked corn & 7.96 & 91.62 & 98.54 & 9.16 & 2.68 & 9.32 & 4.05 & 65.04 & 17.62 \\
\hline Heat-treated soybean meal & 9.04 & 90.80 & 92.31 & 19.74 & 11.22 & 43.92 & 6.20 & 23.84 & 7.74 \\
\hline
\end{tabular}

${ }^{1}$ Soluble protein (Krishnamoorthy et al., 1982).

${ }^{2}$ Mineral mix contained: $44 \% \mathrm{CaCO}_{3} ; 30 \% \mathrm{NaCl} ; 5 \%$ Se $0.06 \%$; $3 \%$ potassium magnesium sulfate; $0.04 \%$ CuSO ${ }_{4}$; $7 \%$ ADE: vitamin A $(6,680$ $\mathrm{kIU} / \mathrm{kg}), \mathrm{D}(3,307 \mathrm{kIU} / \mathrm{kg}), \mathrm{E}(8.907 \mathrm{IU} / \mathrm{kg}) ; 3 \%$ vitamin E (278,000 IU/kg); $7 \%$ trace mineral mix $(26 \% \mathrm{Ca} ; 6 \% \mathrm{~S} ; 303 \mathrm{mg} / \mathrm{kg}$ of Co; $11,000 \mathrm{mg} /$ $\mathrm{kg}$ of $\mathrm{Cu} ; 13,500 \mathrm{mg} / \mathrm{kg}$ of $\mathrm{Fe} ; 909 \mathrm{mg} / \mathrm{kg}$ of I; $20,202 \mathrm{mg} / \mathrm{kg}$ of $\mathrm{Mn} ; 58,589 \mathrm{mg} / \mathrm{kg}$ of Zn).

consumption between ruminants consuming ad libitum or maintenance levels of intake could be attributed to a reduction in visceral tissue mass with unaltered mass-specific tissue oxygen consumption. Additionally, reducing DMI has been shown to reduce fecal output due to both reduced levels of intake and to enhanced digestibility of nutrients provided (Tyrrell and Moe, 1975), although enhanced digestibility is not always observed (Reynolds et al., 1991; Murphy et al., 1994; Bhatti et al., 2008). Reducing energy intake can also precipitate an increase in protein and reduction in fat accretion and can potentially do so without affecting feed efficiency due to the reduced metabolic costs associated with maintenance (Murphy and Loerch, 1994).

Previous research with growing dairy heifers has investigated the impact of $\mathrm{CP}$ requirements relative to ME intake (CP:ME) on growth and mammary development (Lammers and Heinrichs, 2000). Recently, an analysis of literature data for growing milk-fed dairy calves and older heifers demonstrated that the most efficient utilization of dietary $\mathrm{N}$ occurred at CP:ME of 56 $\mathrm{g}$ of $\mathrm{CP} / \mathrm{Mcal}$ of $\mathrm{ME}$, although $\mathrm{N}$ retention continued to increase as CP:ME increased beyond this level (Zanton and Heinrichs, 2008). Due to the potential effects that DMI and CP:ME can have on the efficiency of nutrient utilization, the objective of this research was to evaluate the efficiency of feed and $\mathrm{N}$ utilization and rumen and blood parameters in postpubertal dairy heifers fed 4 levels of DMI at a constant CP:ME determined to maximize gross $\mathrm{N}$ efficiency.

\section{MATERIALS AND METHODS}

\section{Animals, Treatments, and Experimental Design}

All procedures involving the use of animals were approved by the Pennsylvania State University Institutional Animal Care and Use Committee. Eight postpu- bertal Holstein heifers were surgically prepared with a rumen cannula (10.16 cm i.d.; Barr Diamond, Parma, ID) under local anesthesia. Heifers were housed in individual tie-stalls in a mechanically ventilated barn for the duration of the experiment with continuous access to fresh water. For approximately $2 \mathrm{~h}$ before morning feeding on nonsampling days, heifers were allowed access to an exercise lot. The experimental ration (Table 1) was delivered twice daily at 0800 and $2000 \mathrm{~h}$ and provided at 4 levels of DMI covering the range between a level of intake expected to approximate maintenance and ad libitum levels of intake [1.25, 1.50, 1.75, and $2.00 \%$ BW]. The ration was formulated to provide a high forage, poor quality grass-based diet for which rumen fill would be expected to be first-limiting to voluntary DMI. Forages were supplemented with cracked corn and heat-treated soybean meal to increase the energy and CP density of the ration to the formulated levels. Refusals were weighed and collected daily before morning feed delivery. Treatments were administered according to a replicated $4 \times 4$ Latin square design with 35-d periods. On d 0 and 1, 9 and 10, 17 and 18, and 26 and 27 heifers were weighed, with the mean BW of the consecutive days used to adjust DMI allowance for the subsequent days.

\section{Sample Collection and Analysis}

Feed and refusal samples were collected daily, composited by period, dried in a forced air oven at $55^{\circ} \mathrm{C}$ for $48 \mathrm{~h}$, and ground through a 1-mm screen (Wiley mill, Arthur H. Thomas, Philadelphia, PA). Periodcomposited samples were analyzed for DM, ash, and CP (AOAC, 1990), soluble protein (Krishnamoorthy et al., 1982), NDF and ADF (Van Soest et al., 1991), and NSC (Smith, 1981). Analysis of NDF included use of heat-stable a-amylase and sodium sulfite (Van Soest et al., 1991). Metabolizable energy intake was calculated 
for each heifer within each period using the observed digestible OM intake $\times 4.409 \times 0.82(\mathrm{NRC}, 2001)$.

Approximately $7 \mathrm{~h}$ after morning feeding on $\mathrm{d} 11$ of each period, heifers were catheterized in the right jugular vein. Blood samples were taken on d 12 through 13 at 2-h intervals beginning immediately before morning feeding for $24 \mathrm{~h}$. Blood was collected into $10-\mathrm{mL}$ tubes containing sodium heparin as an anticoagulant; samples were immediately centrifuged at $4,000 \times g$ at $4^{\circ} \mathrm{C}$ for $15 \mathrm{~min}$. Plasma was aspirated and stored at $-20^{\circ} \mathrm{C}$ until analysis for urea- $\mathrm{N}$ (procedure no. 0580; Stanbio Laboratory Inc., San Antonio, TX) and glucose (procedure no. 1075; Stanbio Laboratory Inc.).

Beginning on d 13 of each period, $4 \mathrm{~h}$ after morning feeding, in situ bags containing the treatment diet were incubated in the rumen of each heifer to obtain an evaluation of rumen digestion potential and rate. The treatment ration for in situ analysis was collected over d 5 and 6 of each period, composited, dried for 48 $\mathrm{h}$ at $55^{\circ} \mathrm{C}$ in a forced air oven, ground to pass through a 2-mm screen (Wiley mill, Arthur H. Thomas), and 5 $\mathrm{g}$ of sample was weighed into each bag. After soaking for $15 \mathrm{~min}$ in $39^{\circ} \mathrm{C}$ distilled water, bags $(10 \times 20 \mathrm{~cm}$, $53 \mu \mathrm{m}$ pore size) were incubated in the ventral rumen in reverse order for $72,48,24,16,8,4,2$, and $0\left(39^{\circ} \mathrm{C}\right.$ distilled water only) $\mathrm{h}$ and removed simultaneously at $4 \mathrm{~h}$ after morning feeding on $\mathrm{d} 16$ of each period. $\mathrm{Ru}$ men contents were removed from the exterior of the bags manually, before cold water, machine washing 3 times for a 2-min cycle each. Time points within each heifer-period unit were replicated in quadruplicate. Bags were dried at $55^{\circ} \mathrm{C}$ for $48 \mathrm{~h}$, weighed, and composited by heifer-period-time point for chemical analysis. Composited samples were subsequently ground and analyzed for NDF and CP in a manner consistent with feed samples.

On d 23 for square A and d 32 for square B of each period, rumen fluid samples were collected at 2 -h intervals beginning at morning feeding for $24 \mathrm{~h}$ from the dorsal, caudal, and ventral areas of the rumen. Whole rumen samples were mixed by hand and squeezed through 4 layers of cheesecloth before immediately analyzing rumen fluid for $\mathrm{pH}$ (pH meter, model M90, Corning Inc., Corning, NY). A $15-\mathrm{mL}$ subsample was stored at $-20^{\circ} \mathrm{C}$ with $3 \mathrm{~mL} \mathrm{25 \%}$ metaphosphoric acid and with $3 \mathrm{~mL}$ of $0.6 \%$ 2-ethyl butyric acid as an internal standard. Thawed samples were centrifuged 3 times at 4,000 $\times g$ for $30 \mathrm{~min}$ at $4^{\circ} \mathrm{C}$ and the clear supernatant was retained for analysis of VFA and ammonia as detailed in Moody et al. (2007). On d 25 for square A and d 34 for square B beginning $6 \mathrm{~h}$ after morning feeding, the complete contents of the reticulo-rumen were removed. Immediately before evacuation, access to feed and water was removed. Rumen contents were weighed, mixed thoroughly, and subsampled before replacing the remaining contents into the rumen of each heifer. Samples were frozen and stored at $-20^{\circ} \mathrm{C}$ until freeze drying, grinding, and subsequent chemical analysis in a manner similar to feed.

On d 20 for square A and d 29 for square B of each period, heifers were urinary catheterized (no. 14 French balloons; Rusch Inc., Duluth, GA) before feeding for a 6 -d total collection of urine and feces. Urine was collected continuously into a 25 -L container, which was maintained at $\mathrm{pH}<3$ by the addition of $12 \mathrm{~N} \mathrm{HCl}$. Urine and feces were weighed daily immediately after morning feeding, and a representative subsample was removed for subsequent analysis. Feces were dried, ground, and analyzed for ash, N, NDF, and ADF in a manner consistent with feed samples. Urine samples were stored at $-20^{\circ} \mathrm{C}$ until thawed and analyzed for N (AOAC, 1990) and purine derivatives (Chen and Gomes, 1992).

\section{Statistical Analysis and Calculations}

Bacterial CP flow to the duodenum was calculated according to the methodology and equations presented by Chen and Gomes (1992). Parameters of the in situ degradation profiles were estimated using the nonlinear mixed model procedure of SAS (2006), where fixed parameter estimates of period and diet and random parameter estimates of heifer were simultaneously modeled within the context of the first-order exponential degradation model with discrete lag.

Because the heifers completing this experiment were growing and previous level of nutrition may have substantial influence on nutrient utilization during subsequent periods of growth, treatments in this experiment were administered to account for the carryover effect from the previous period into the current period. Heifers within squares were randomized to treatment sequences, and treatment sequences were arranged so that every treatment followed every other treatment but itself. The final analyses were conducted according to the following mixed model in SAS (2006):

$$
\mathrm{Y}_{\mathrm{ijklm}}=\mu+\mathrm{S}_{\mathrm{i}}+\mathrm{P}_{\mathrm{j}}+\mathrm{T}_{\mathrm{k}}+\mathrm{C}_{\mathrm{l}}+\mathrm{h}_{\mathrm{m}(\mathrm{i})}+\mathrm{e}_{\mathrm{ijklm}},
$$

where $\mathrm{Y}_{\mathrm{ijk} l \mathrm{~m}}=$ dependent variable; $\mu=$ overall mean response; $\mathrm{S}_{\mathrm{i}}=$ fixed effect of square, $\mathrm{i}=1,2 ; \mathrm{P}_{\mathrm{j}}=$ fixed effect of period, $\mathrm{j}=1, \ldots, 4 ; \mathrm{T}_{\mathrm{k}}=$ fixed effect of treatment, $\mathrm{k}$ $=1, \ldots, 4 ; \mathrm{C}_{1}=$ fixed effect of carryover effect from previous treatment, $\mathrm{l}=1, \ldots, 4 ; \mathrm{h}_{\mathrm{m}(\mathrm{i})}=$ random effect of heifer within square, $\mathrm{m}=1, \ldots, 4 ; \mathrm{e}_{\mathrm{ijk} l m}=$ residual error.

In modeling the random heifer effect, there was strong evidence of heterogeneous variance across pe- 
Table 2. Body weight, DMI, N and ME intake, and CP:ME for dairy heifers limit-fed a high forage ration at 4 levels of DMI

\begin{tabular}{|c|c|c|c|c|c|c|c|}
\hline Item & \multicolumn{4}{|c|}{ DM offered, \% of BW } & SE & \multicolumn{2}{|c|}{$P$-value } \\
\hline $\mathrm{BW}, \mathrm{kg}$ & 343 & 358 & 373 & 377 & 7 & $<0.001$ & 0.008 \\
\hline \multicolumn{8}{|l|}{ DMI } \\
\hline $\mathrm{kg} / \mathrm{d}$ & 4.27 & 5.47 & 6.46 & 7.36 & 0.10 & $<0.001$ & 0.118 \\
\hline$\%$ of BW (actual) & 1.24 & 1.48 & 1.73 & 1.95 & 0.01 & $<0.001$ & 0.993 \\
\hline Refused, ${ }^{1} \%$ & $0.01^{\mathrm{c}}$ & $0.11^{\mathrm{bc}}$ & $0.25^{\mathrm{b}}$ & $1.76^{\mathrm{a}}$ & 0.02 & - & - \\
\hline $\mathrm{ME},^{2} \mathrm{kcal}$ & 125 & 150 & 170 & 193 & 2 & $<0.001$ & 0.744 \\
\hline CP:ME, g/Mcal & 55.5 & 56.2 & 58.1 & 58.4 & 0.5 & 0.004 & 0.811 \\
\hline
\end{tabular}

${ }^{a-c}$ Values with different superscripts differ after back-transformation, $P<0.05$.

${ }^{1}$ Percent of feed offered that was refused. Response was not normally distributed-analyzed as $\sqrt[3]{\text { Refusals }}$ and presented as back-transformed data.

${ }^{2} \mathrm{ME}=$ observed digestible $\mathrm{OM}$ intake $\times 4.409 \times 0.82$.

riods and autocorrelation between residuals of acrossperiod repeated measures. The first-order antedependence covariate structure was included as a means to account for each of these sources of random variation for instances where 1 measurement was recorded per period. When multiple observations were recorded over time within period, heifer(period) was considered the random effect with repeated measures modeled with the first-order autoregressive covariance structure.

Denominator degrees of freedom and standard errors were calculated according to the Kenward-Roger small sample adjustment. Residual analysis was conducted for assessing the assumption of normality and the presence of outliers. Because treatments were 4 levels of DMI as a percentage of $\mathrm{BW}$ and because the prevalence of refusals increased as the level of DM offered was increased, the observed treatment levels were not evenly spaced. To account for this observation, the method of Robson (1959) was used to construct linear and quadratic contrasts using the average DMI as a percentage of BW determined for each treatment. Least squares means are presented and significance and tendency toward significance are declared where $P<0.05$ and 0.10 , respectively.

\section{RESULTS AND DISCUSSION}

The objective of this work was to evaluate the nutritional efficiency of a high forage diet restricted to 4 levels of DMI at a CP:ME demonstrated to maximize efficiency of $\mathrm{N}$ utilization. The composition of the grass-based ration is shown in Table 1 . The ration was formulated with $81 \%$ of dietary DM from forage and $70 \%$ of the forage as grass silage or hay. Concentration of NDF was $49 \%$ and levels of DM offered increased from 1.25 to $2.00 \% \mathrm{BW}$. The ME offered at the highest level of intake was sufficient to maintain ADG of approximately $600 \mathrm{~g} / \mathrm{d}$ (NRC, 2001), lower than current practical recommendations, but sufficiently low to reduce the possibility that energy requirements would limit DMI. Observed ADG during collection was 598.7 $\mathrm{g} / \mathrm{d}$ for $2.00 \% \mathrm{BW}$ treatment, which decreased linearly as DMI decreased, though the absolute levels of ADG may be of questionable accuracy in an experiment with short periods.

Dry matter offered to heifers in this experiment was based on BW recorded the previous week. However, actual DMI was lower than the quantity offered, particularly at the highest level of DMI, due to greater refusals as DM offered increased (Table 2). In an effort to estimate the point at which the DMI did not increase with increasing DM offered, a piecewise linear regression analysis was conducted regressing the independent variable DM offered against the dependent variable DMI. Under the conditions of the current experiment, heifers fed the high forage, silage-based diet consumed feed in direct proportion to the amount offered until DM offered was $1.92 \%$ BW $(1.88,1.96 ; 95 \%$ confidence limits) or when NDF offered was $0.966 \%$ BW (0.934, 0.997), after which an intake failed to increase significantly.

Results of in situ degradation kinetics are presented in Table 3 for DM, NDF, and CP. In situ analysis was included as an experimental outcome in this study in an effort to separate alterations in the rate of feed degradation in the rumen from observed differences in total tract digestion that may be attributed to alterations in retention time of feed in the rumen. Vanzant et al. (1998) reported that although recommended levels of intake for the investigation of in situ degradation kinetics range from maintenance to ad libitum consumption of feed, comprehensive data on the relation- 
Table 3. Least squares means of in situ degradation kinetics ${ }^{1}$ of ration DM, NDF, and CP for dairy heifers limit-fed a high forage ration at 4 levels of DMI

\begin{tabular}{|c|c|c|c|c|c|c|c|}
\hline Item & \multicolumn{4}{|c|}{ DM offered, $\%$ of BW } & $\mathrm{SE}$ & \multicolumn{2}{|c|}{$P$-value } \\
\hline $\mathrm{D}, \%$ & 42.9 & 42.9 & 41.4 & 42.0 & 1.3 & 0.314 & 0.843 \\
\hline U, \% & 19.7 & 19.2 & 20.6 & 19.8 & 0.8 & 0.486 & 0.849 \\
\hline $\mathrm{k}, \% / \mathrm{h}$ & 5.35 & 4.71 & 5.86 & 5.28 & 0.37 & 0.332 & 0.814 \\
\hline $\mathrm{D}, \%$ & 58.72 & 67.15 & 66.18 & 63.37 & 5.68 & 0.170 & 0.107 \\
\hline U, \% & 30.52 & 26.85 & 31.04 & 28.93 & 1.50 & 0.904 & 0.473 \\
\hline $\mathrm{k}, \% / \mathrm{h}$ & 5.10 & 3.85 & 4.73 & 4.42 & 0.31 & 0.229 & 0.056 \\
\hline \multicolumn{8}{|l|}{$\mathrm{CP}$} \\
\hline Lag, h & 6.37 & 7.51 & 6.05 & 6.49 & 0.64 & 0.513 & 0.485 \\
\hline $\mathrm{D}, \%$ & 39.95 & 36.77 & 37.37 & 38.56 & 1.73 & 0.478 & 0.177 \\
\hline U, \% & 8.35 & 10.66 & 11.87 & 9.85 & 1.59 & 0.226 & 0.161 \\
\hline
\end{tabular}

${ }^{1} \mathrm{D}=$ potentially degradable and $\mathrm{U}=$ undegradable expressed as percentage of sample. All feed components modeled according to the mixed effects, covariate extension of $\mathrm{Y}=\mathrm{U}+\mathrm{D} \times \mathrm{e}^{-\mathrm{k}(\mathrm{t}-\mathrm{lag})}$, for $\mathrm{t}>\mathrm{lag}$, where $\mathrm{t}=$ time and $\mathrm{k}=$ rate of digestion.

ship between level of intake and in situ degradation were lacking. Prigge et al. (1984) found no significant differences attributable to intake level in the in situ degradation of 2 hays by either sheep or cattle. Likewise, Firkins et al. (1986) did not observe altered in situ $\mathrm{N}$ degradation for beef steers offered 2 levels of feed intake. Recently, Bhatti et al. (2008) found that DMI levels of ad libitum or 1\% of BW did not affect any parameters of DM or NDF in situ degradation of orchardgrass hay. From the results of the current experiment for DM, NDF, and CP it cannot be inferred that alterations in DMI in the range used here led to substantial alterations in degradation kinetics of this high forage diet. Rates of digestion for NDF and CP tended to change as level of intake increased $(P<0.056$ and $P<$ 0.057 for quadratic and linear contrasts, respectively); however, the numerical differences realized are likely of limited biological importance. The sole parameter for which there was any evidence for a significant intake effect was the discrete lag for NDF, which responded linearly and quadratically to alterations in DMI and was minimized for heifers fed $1.75 \% \mathrm{BW}$. The rate of NDF degradation tended to respond quadratically to alterations in DMI; thus, the combined effect of these differences was in situ degradation curves that were nearly coincident across intakes. From these results, it cannot be concluded that the rate of dietary DM, NDF, or CP degradation was impacted by level of intake under the conditions of the current experiment.

Pool sizes of rumen contents and relationships to BW and intake are presented in Table 4. Mass of whole rumen contents, liquid, and DM increased linearly with increasing levels of DM offered. Whereas DMI was $72 \%$ greater for heifers fed 2.00 than heifers fed $1.25 \% \mathrm{BW}$, the increase in whole rumen contents, liquid, and DM was disproportionate to the increase in DMI; being only 23,20 , and $34 \%$ greater for heifers fed $2.00 \%$ BW than heifers fed $1.25 \%$ BW, respectively. Dry rumen contents and NDF mass increased linearly with increasing DMI, in part due to a significant increase in the concentration of DM in whole rumen contents. Rumen DM and NDF per unit of intake declined significantly as intake increased, suggesting that increased passage rate may have occurred as intake increased. Because rate and extent of in situ degradation were not altered due to the level of dietary intake, the response observed in rumen turnover in this experiment was apparently due to increases in passage of material through the omasal canal as has been observed several times previously (Firkins et al., 1987; Murphy et al., 1994).

Although whole rumen content mass was linearly altered by intake level and BW increased linearly and quadratically with intake level, relating whole rumen contents to BW by heifer within period resulted in a significant linear increase in whole rumen contents as intake increased. Whole rumen contents were maximized at $12.9 \%$ of BW when DM offered was either 1.75 or $2.00 \%$ BW. Waldo et al. (1965) measured the weight of rumen contents for Holstein heifers fed grass-alfalfa forage conserved as either hay or silage for ad libitum consumption. The heifers fed hay ad libitum had whole rumen contents of $15.1 \% \mathrm{BW}$ while consuming $2.06 \%$ $\mathrm{BW}$, and the heifers fed silage ad libitum had whole rumen contents of $13.2 \%$ BW while consuming $1.70 \%$ BW. Likewise, Bailey (1986) fed Holstein steers a diet composed entirely of hay and found an average whole 
Table 4. Rumen pool sizes of whole rumen contents, DM, liquid, OM, NDF, and ADF for dairy heifers limit-fed a high forage ration at 4 levels of DMI

\begin{tabular}{|c|c|c|c|c|c|c|c|}
\hline \multirow[b]{2}{*}{ Item } & \multicolumn{4}{|c|}{ DM offered, \% of BW } & \multirow[b]{2}{*}{$\mathrm{SE}$} & \multicolumn{2}{|c|}{$P$-value } \\
\hline & 1.25 & 1.50 & 1.75 & 2.00 & & Linear & Quadratic \\
\hline Liquid $^{1}$ & 35.08 & 37.69 & 41.52 & 42.21 & 1.32 & 0.001 & 0.470 \\
\hline DM & 5.19 & 5.37 & 6.65 & 6.98 & 0.22 & $<0.001$ & 0.615 \\
\hline $\mathrm{NDF}$ & 3.50 & 3.72 & 4.58 & 5.01 & 0.15 & $<0.001$ & 0.361 \\
\hline DM & 1.16 & 1.04 & 1.04 & 0.95 & 0.04 & 0.002 & 0.702 \\
\hline NDF & 1.61 & 1.49 & 1.49 & 1.34 & 0.04 & $<0.001$ & 0.746 \\
\hline \multicolumn{8}{|l|}{$\%$ of BW } \\
\hline Whole contents & 11.7 & 12.4 & 12.9 & 12.9 & 0.3 & 0.017 & 0.292 \\
\hline Liquid $^{1}$ & 10.2 & 10.8 & 11.2 & 11.0 & 0.3 & 0.041 & 0.192 \\
\hline DM & 1.5 & 1.6 & 1.8 & 1.8 & 0.1 & $<0.001$ & 0.947 \\
\hline $\mathrm{NDF}$ & 1.0 & 1.1 & 1.2 & 1.3 & 0.1 & $<0.001$ & 0.670 \\
\hline
\end{tabular}

${ }^{1}$ Rumen liquid was determined as weight lost after freeze-drying.

rumen contents across all $\mathrm{BW}$ of $13.4 \% \mathrm{BW}$ at slaughter weights between 100 and $500 \mathrm{~kg}$. The NRC (2001) calculates empty BW for the prediction of protein and energy requirements for growing dairy heifers as $85.5 \%$ of full BW. Given the preceding discussion of the relative mass of rumen contents, this conversion factor seems to be somewhat higher than may be required for Holstein heifers full-fed a high forage diet since the rumen content empty BW alone averaged $87.1 \%$ of full BW when DMI was offered at 1.75 and $2.00 \%$ BW in the current trial.

Blood glucose and urea-N were not altered by intake level as shown in Table 5. Rumen $\mathrm{pH}$ declined and concentration of VFA increased as level of intake increased, reflecting the greater consumption of fermentable substrate relative to end product utilization as intake level increased. Whereas differences in rumen $\mathrm{pH}$ declined linearly as intake increased, the magnitude of these changes is likely of limited biological significance because the range of values differs only by 0.08 units. Average daily rumen $\mathrm{NH}_{3}$ concentration was unaffected by feeding level as has been found previously in vivo (Firkins et al., 1986) and in continuous culture (Schadt et al., 1999). All feeding levels maintained average rumen $\mathrm{NH}_{3}$ concentration significantly lower than the recommended concentration of $5 \mathrm{mg} / \mathrm{dL}$; however, the average daily rumen $\mathrm{NH}_{3}$ concentration was $>2 \mathrm{mg} /$ $\mathrm{dL}$, the amount determined to be the precise limiting concentration of $\mathrm{NH}_{3}$ to support maximum microbial growth (Satter and Slyter, 1974). The amount of time during the day in which the concentration of $\mathrm{NH}_{3}$ may have limited microbial fermentation (time when $\mathrm{NH}_{3}$ concentration $<5 \mathrm{mg} / \mathrm{dL}$ ) also was unaffected by level of intake and averaged $16.7 \mathrm{~h}$ across intake levels with an average $\mathrm{NH}_{3}$ concentration over this time of 2.64 $\mathrm{mg} / \mathrm{dL}$.

Table 5. Blood glucose and urea-N and rumen $\mathrm{pH}, \mathrm{NH}_{3}-\mathrm{N}$, and VFA concentrations for dairy heifers limit-fed a high forage ration at 4 levels of DMI

\begin{tabular}{|c|c|c|c|c|c|c|c|}
\hline \multirow[b]{2}{*}{ Item } & \multicolumn{4}{|c|}{ DM offered, \% of BW } & \multirow[b]{2}{*}{$\mathrm{SE}$} & \multicolumn{2}{|c|}{$P$-value } \\
\hline & 1.25 & 1.50 & 1.75 & 2.00 & & Linear & Quadratic \\
\hline $\mathrm{pH}$ & 6.86 & 6.81 & 6.79 & 6.78 & 0.04 & 0.040 & 0.383 \\
\hline $\mathrm{NH}_{3}-\mathrm{N}, \mathrm{mg} / \mathrm{dL}$ & 3.87 & 4.26 & 4.13 & 4.16 & 0.16 & 0.274 & 0.237 \\
\hline $\mathrm{VFA}, \mathrm{m} M$ & 107 & 114 & 119 & 122 & 3 & $<0.001$ & 0.504 \\
\hline \multicolumn{8}{|c|}{ VFA, molar $\%$ of total VFA } \\
\hline Propionate & 19.40 & 19.42 & 19.46 & 19.43 & 0.19 & 0.814 & 0.871 \\
\hline Butyrate & 8.93 & 9.09 & 8.94 & 9.15 & 0.12 & 0.098 & 0.761 \\
\hline Valerate & 1.56 & 1.52 & 1.53 & 1.52 & 0.03 & 0.305 & 0.552 \\
\hline Isobutyrate & 1.29 & 1.20 & 1.16 & 1.11 & 0.02 & $<0.001$ & 0.508 \\
\hline Isovalerate & 1.76 & 1.63 & 1.58 & 1.52 & 0.02 & $<0.001$ & 0.146 \\
\hline
\end{tabular}


Table 6. Urinary purine derivative excretion and estimated bacterial CP flow for dairy heifers limit-fed a high forage ration at 4 levels of DMI

\begin{tabular}{|c|c|c|c|c|c|c|c|}
\hline Item & \multicolumn{4}{|c|}{ DM offered, \% of BW } & $\mathrm{SE}$ & \multicolumn{2}{|c|}{$P$-value } \\
\hline Allantoin, mmol & 89.6 & 88.6 & 107.0 & 118.2 & 7.7 & $<0.001$ & 0.101 \\
\hline Purine derivatives, mmol & 99.0 & 97.8 & 118.7 & 133.0 & 8.3 & $<0.001$ & 0.057 \\
\hline \multicolumn{8}{|l|}{ Bacterial $\mathrm{CP}^{1}$} \\
\hline $\mathrm{g} / \mathrm{d}$ & 375 & 408 & 500 & 533 & 55 & 0.048 & 0.930 \\
\hline
\end{tabular}

${ }^{1}$ Estimated according to the methods and equations of Chen and Gomes (1992).

Molar proportions of VFA were not affected by feeding level with acetate, propionate, and butyrate averaging $67.2,19.4$, and 9.0 molar percent of total VFA, respectively, proportions consistent with the high forage diet consumed. As level of intake increased, molar proportions of iso-acids declined linearly due to unchanged concentrations of these VFA and concurrent increases in all other VFA measured. The observed reduction in iso-acid molar proportions is consistent with continuous culture results reported by Schadt et al. (1999) and may reflect enhanced fermentation of dietary branchedchain AA when intake of fermentable carbohydrate is low, increased utilization of iso-acids and $\mathrm{NH}_{3}$ for biosynthesis of branched-chain AA when the turnover of rumen contents is increased with increasing intake, or both.

Bacterial CP flow to the duodenum was estimated through the evaluation of purine derivatives excreted in the urine (Table 6). Allantoin and uric acid excretion increased significantly with increasing DMI, with total purine derivative excretion in close association with individual components. Bacterial CP predicted to flow to the duodenum was increased linearly with increasing DMI, which is consistent with previous results (Firkins et al., 1986; Firkins et al., 1987; Murphy et al., 1994). An average of $61 \%$ of dietary CP flowed to the duodenum as bacterial CP, but was not necessarily formed directly from dietary $\mathrm{CP}$ as this value does not take into account recycling of $\mathrm{N}$ within and to the rumen. The efficiency of production per unit intake of CP was unaffected by feeding level, which differs from many results [Firkins et al., 1986; Murphy et al., 1994 (trial 2); Schadt et al., 1999], but not all [Firkins et al., 1987; Murphy et al., 1994 (trial 1)]. The variability associated with bacterial CP flow measured in the current experiment was rather high, and this enhanced variability cannot be discounted as an explanation for the similarity of the efficiency values observed.

Manure, fecal and urinary output, as well as digestibility are presented in Table 7. Total manure increased as DMI increased, closely following the excretion of wet feces because the excretion of urine was not different between diets and averaged $9.36 \mathrm{~kg} / \mathrm{d}$. The reduction in fecal excretion with reduced intake was not unexpected due simply to the reduced amount of material consumed. However, the incremental increase in total manure and wet fecal excretion was out of proportion to changes in DMI (Figure 1). Regression analysis indicated that as DMI increased $1 \mathrm{~kg} / \mathrm{d}$, total manure and wet fecal excretion increased $2.54 \mathrm{~kg} / \mathrm{d}$. There are $2 \mathrm{ex}$ planations for this observation: first, as DMI increases the concentration of DM in wet feces declines resulting in greater fecal excretion of water; second, digestibility of dietary DM decreases as DMI increases (Table 7). Whereas inverse changes in digestibility and intake are often observed (Firkins et al., 1986, 1987), reduction in digestibility is not always associated with altered DMI (Reynolds et al., 1991; Murphy et al., 1994; Bhatti et al., 2008). The level of DM digestibility reduction observed in the current experiment, though statistically significant, was only 2 percentage units.

Limit-feeding concentrate diets with greater digestibility to dairy heifers as a means of improving feed efficiency (Hoffman et al., 2007; Zanton and Heinrichs, 2007) and reducing manure excretion (Moody et al., 2007) has been examined recently as an alternative to high forage diets for dairy heifers. The results of this trial also show that limit-feeding can result in reductions in manure excretion when a high forage diet is fed; however, the level of improvement observed in manure excretion (2.54 kg of manure/kg of DMI) in the current experiment is rather modest compared with the improvements that can be realized when both diet intake and composition are altered simultaneously (10.2 $\mathrm{kg}$ of manure $/ \mathrm{kg}$ of DMI, for instance, from the results of Moody et al., 2007).

Other research has attempted to reduce manure excretion by dairy heifers limit-fed high concentrate diets, but did not succeed because although wet fecal excretion was reduced, urine excretion was enhanced considerably (Hill et al., 2007). These authors speculated that the increase in urine excretion was due to 
alterations in behavior associated with limited provision of DM for heifers fed the high concentrate diet. Although this hypothesis cannot be rejected from the results of the current experiment, the constant level of urine excretion observed for all intake levels in the current experiment cast doubt upon this explanation because the level of restriction imposed in the current experiment was more severe than that imposed by Hill et al. (2007). The results of Moody et al. (2007) also failed to demonstrate a significant increase in urine output for heifers limit-fed high or low concentrate corn silage-based rations. Although alterations in behavior are not uncommon for limit-fed dairy heifers (Hoffman et al., 2007), this alone seems an insufficient explanation for the enhanced urine excretion that can be observed in such heifers.

Table 8 shows the results of $\mathrm{N}$ balance and digestibility. Increasing intake linearly increased all aspects of $\mathrm{N}$ partitioning measured. Although results due to increases in $\mathrm{N}$ intake cannot be distinguished from increases in energy intake, the significant linear and the lack of a significant quadratic effect of $\mathrm{N}$ retention to increasing intake lead to the inference that either $\mathrm{N}$ or energy intake limited $\mathrm{N}$ retention under these experimental conditions, but at a similar level across all levels of intake. Nitrogen was retained at a marginal efficiency of $37.2 \%$ across all intakes, which was not different than the average marginal efficiency of $31.4 \%$ predicted from the random effects regression equation presented by Zanton and Heinrichs (2008, $P>0.229)$ when $\mathrm{N}$ intake was altered alone.

Apparent digestibility of $\mathrm{N}$ responded at a level that was entirely consistent with alterations in digestibility of other dietary components. Using the value of $6.51 \mathrm{~g}$ of nondietary fecal $\mathrm{N}$ per $\mathrm{kg}$ of DMI obtained by Zanton and Heinrichs (2008) for heifers consuming many varied diets, a true $\mathrm{N}$ digestibility of $100.4 \%$ was predicted across all intakes $(P>0.09)$, a value that is higher than

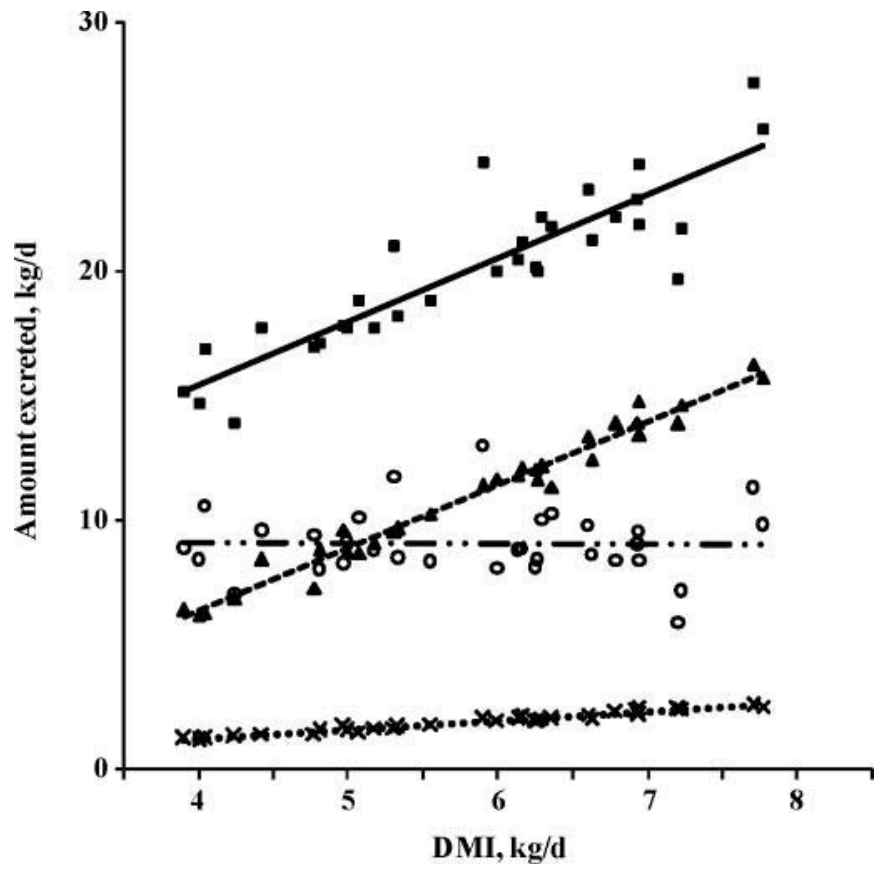

Figure 1. Excretion of manure components for dairy heifers limitfed a high forage ration at 4 levels of DMI as a percentage of BW $(1.25 ; 1.50 ; 1.75$; and $2.00 \% \mathrm{BW})$. Total manure output $(\mathbf{\square})$ is related to DMI $(\mathrm{kg} / \mathrm{d})$ by the equation: manure output $(\mathrm{kg} / \mathrm{d})=5.33( \pm 2.41)+$ $2.54( \pm 0.35) \times$ DMI $\left(-, R^{2}=0.781\right)$. Wet fecal output $(\mathbf{\Delta})$ is related to DMI $(\mathrm{kg} / \mathrm{d})$ by the equation: wet fecal output $(\mathrm{kg} / \mathrm{d})=-3.77( \pm 0.62)$ $+2.54( \pm 0.11) \times$ DMI, $\left(---, R^{2}=0.971\right)$. Urine output (o) is related to DMI $(\mathrm{kg} / \mathrm{d})$ by the equation: urine output $(\mathrm{kg} / \mathrm{d})=9.18( \pm 2.25)-$ $0.02( \pm 0.33) \times$ DMI $\left(-\cdot-, R^{2}=0.000\right)$. Dry feces output $(\times)$ is related to DMI $(\mathrm{kg} / \mathrm{d})$ by the equation: dry feces output $(\mathrm{kg} / \mathrm{d})=-0.20( \pm 0.08)$ $+0.37( \pm 0.01) \times$ DMI $\left(\cdots \cdots \cdots, R^{2}=0.972\right)$.

the $96.4 \%$ obtained through a regression approach by those authors. Thus, due to differences in DMI, the majority of fecal $\mathrm{N}$ excretion and differences in $\mathrm{N}$ digestibility likely resulted from increases in nondietary fecal $\mathrm{N}$ excretion, although the absolute level of nondietary fecal $\mathrm{N}$ excretion in this experiment was likely lower than that obtained by Zanton and Heinrichs (2008).

Table 7. Manure, fecal, urine, and DM output and digestibility of ration DM, OM, and NDF for dairy heifers limit-fed a high forage ration at 4 levels of DMI

\begin{tabular}{|c|c|c|c|c|c|c|c|}
\hline \multirow[b]{2}{*}{ Item } & \multicolumn{4}{|c|}{ DM offered, \% of BW } & \multirow[b]{2}{*}{$\mathrm{SE}$} & \multicolumn{2}{|c|}{$P$-value } \\
\hline & 1.25 & 1.50 & 1.75 & 2.00 & & Linear & Quadratic \\
\hline Total & 15.56 & 19.72 & 23.16 & 23.29 & 1.35 & $<0.001$ & 0.091 \\
\hline Wet feces & 7.42 & 9.82 & 12.52 & 14.63 & 0.48 & $<0.001$ & 0.987 \\
\hline Urine & 8.47 & 9.21 & 9.93 & 9.85 & 1.36 & 0.197 & 0.666 \\
\hline \multicolumn{8}{|l|}{ Fecal DM } \\
\hline \multicolumn{8}{|l|}{ Digestibility, \% } \\
\hline DM & 68.33 & 67.40 & 66.69 & 66.34 & 0.45 & 0.004 & 0.494 \\
\hline $\mathrm{OM}$ & 69.65 & 68.81 & 67.98 & 67.53 & 0.45 & 0.001 & 0.650 \\
\hline NDF & 61.84 & 60.94 & 60.14 & 59.33 & 0.92 & 0.053 & 0.999 \\
\hline
\end{tabular}


Table 8. Nitrogen partitioning and efficiency for dairy heifers limit-fed a high forage ration at 4 levels of DMI

\begin{tabular}{|c|c|c|c|c|c|c|c|}
\hline Item & \multicolumn{4}{|c|}{ DM offered, \% of BW } & $\mathrm{SE}$ & \multicolumn{2}{|c|}{$P$-value } \\
\hline \multicolumn{8}{|l|}{$\mathrm{N}$ partitioning, g/d } \\
\hline Digested & 61.85 & 77.57 & 91.47 & 106.14 & 2.31 & $<0.001$ & 0.891 \\
\hline Feces & 26.90 & 34.31 & 43.01 & 46.75 & 1.20 & $<0.001$ & 0.354 \\
\hline Urine & 45.19 & 52.50 & 58.74 & 68.23 & 1.60 & $<0.001$ & 0.238 \\
\hline \multicolumn{8}{|l|}{$\mathrm{N}$ efficiency, \% } \\
\hline Digested/intake & 70.25 & 69.85 & 68.82 & 68.26 & 0.64 & 0.011 & 0.816 \\
\hline Retained/intake & 18.09 & 23.31 & 24.83 & 23.00 & 1.98 & 0.074 & 0.080 \\
\hline Retained/digested & 25.33 & 33.59 & 36.08 & 33.40 & 2.87 & 0.047 & 0.066 \\
\hline Retained/excreted & 23.61 & 33.01 & 33.81 & 33.44 & 3.10 & 0.048 & 0.110 \\
\hline
\end{tabular}

Efficiency of $\mathrm{N}$ utilization tended to be (per unit $\mathrm{N}$ intake) or was significantly (per unit digested or excreted) improved as intake increased, although it is clear from the tendency for a quadratic response that a substantial portion of these responses was due to heifers fed $1.25 \% \mathrm{BW}$ retaining $\mathrm{N}$ at a much lower efficiency than the other intake levels. This situation arose due to a disproportionately lower level of $\mathrm{N}$ excreted in the urine as intake increased, which may be due to an enhanced utilization of absorbed AA as an energy source or for the synthesis of glucose with low intake (Orskov et al., 1999). Intake above $1.25 \% \mathrm{BW}, \mathrm{N}$ retention accounted for only $23.7 \%$ of $\mathrm{N}$ intake, values that do not differ from what would be expected based on $\mathrm{N}$ intake of this trial and the gross $\mathrm{N}$ efficiency response to $\mathrm{N}$ intake alone reported by Zanton and Heinrichs (2008, $P>0.462)$.

\section{CONCLUSIONS}

From the results of this experiment, it was determined that whole rumen contents represented $12.9 \%$ BW for heifers offered DM at 1.75 or $2.00 \%$ BW, a level higher than that which would be consistent with the conversion factor for calculating EBW utilized by the NRC (2001). It can be concluded that when dairy heifers were fed a high forage diet at intakes between levels approximating maintenance and ad libitum consumption, the efficiency of nutrient utilization was increased as intake decreased. The increases in efficiency due to alterations in DMI alone were minimal for the high forage diet fed in the current experiment compared with experiments in which both DMI and diet composition were altered concurrently. Under the conditions of the current experiment, $\mathrm{N}$ retention increased linearly, but the efficiency of $\mathrm{N}$ retention attained maximum levels for all levels of intake above $1.25 \% \mathrm{BW}$. The $\mathrm{N}$ partitioning observations of this experiment where $\mathrm{CP}: \mathrm{ME}$ was fixed at a level hypothesized to maximize the efficiency of $\mathrm{N}$ utilization did not differ from previous results where the intake of $\mathrm{N}$ alone was altered and ME was maintained constant.

\section{ACKNOWLEDGMENTS}

The authors would like to thank West Central for donating the heat-treated soybean meal (SoyPLUS) fed in this experiment.

\section{REFERENCES}

Association of Official Analytical Chemists. 1990. Official Methods of Analysis. 15th ed. AOAC, Arlington, VA.

Bailey, C. B. 1986. Growth of digestive organs and their contents in Holstein steers-Relation to body-weight and diet. Can. J. Anim. Sci. 66:653-661.

Bhatti, S. A., J. G. Bowman, J. L. Firkins, A. V. Grove, and C. W. Hunt. 2008. Effect of intake level and alfalfa substitution for grass hay on ruminal kinetics of fiber digestion and particle passage in beef cattle. J. Anim. Sci. 86:134-145.

Chen, X. B., and M. J. Gomes. 1992. Estimation of microbial protein supply to sheep and cattle based on urinary excretion of purine derivatives-An overview of the technical details. International Feed Resources Unit, Rowett Research Institute, Occasional Publication, Aberdeen.

Firkins, J. L., L. L. Berger, N. R. Merchen, G. C. Fahey, and D. R. Nelson. 1986. Effects of feed-intake and protein degradability on ruminal characteristics and site of digestion in steers. J. Dairy Sci. 69:2111-2123.

Firkins, J. L., S. M. Lewis, L. Montgomery, L. L. Berger, N. R. Merchen, and G. C. Fahey Jr. 1987. Effects of feed intake and dietary urea concentration on ruminal dilution rate and efficiency of bacterial growth in steers. J. Dairy Sci. 70:2312-2321.

Hill, S. R., K. F. Knowlton, R. E. James, R. E. Pearson, G. L. Bethard, and K. J. Pence. 2007. Nitrogen and phosphorus retention and excretion in late-gestation dairy heifers. J. Dairy Sci. 90:56345642.

Hoffman, P. C., N. M. Brehm, S. G. Price, and A. Prill-Adams. 1996. Effect of accelerated postpubertal growth and early calving on lactation performance of primiparous Holstein heifers. J. Dairy Sci. 79:2024-2031. 
Hoffman, P. C., C. R. Simson, and M. Wattiaux. 2007. Limit feeding of gravid Holstein heifers: Effect on growth, manure nutrient excretion, and subsequent early lactation performance. J. Dairy Sci. 90:946-954.

Krishnamoorthy, U., T. V. Muscato, C. J. Sniffen, and P. J. Van Soest. 1982. Nitrogen fractions in selected feedstuffs. J. Dairy Sci. 65:217-225.

Lammers, B. P., and A. J. Heinrichs. 2000. The response of altering the ratio of dietary protein to energy on growth, feed efficiency, and mammary development in rapidly growing prepubertal heifers. J. Dairy Sci. 83:977-983.

McLeod, K. R., and R. L. Baldwin. 2000. Effects of diet forage:concentrate ratio and metabolizable energy intake on visceral organ growth and in vitro oxidative capacity of gut tissues in sheep. J. Anim. Sci. 78:760-770.

Moody, M. L., G. I. Zanton, J. M. Daubert, and A. J. Heinrichs. 2007. Nutrient utilization of differing forage-to-concentrate ratios by growing Holstein heifers. J. Dairy Sci. 90:5580-5586.

Murphy, T. A., and S. C. Loerch. 1994. Effects of restricted feeding of growing steers on performance, carcass characteristics, and composition. J. Anim. Sci. 72:2497-2507.

Murphy, T. A., S. C. Loerch, and B. A. Dehority. 1994. The influence of restricted feeding on site and extent of digestion and flow of nitrogenous compounds to the duodenum in steers. J. Anim. Sci. 72:2487-2496.

National Research Council. 2001. Nutrient Requirements of Dairy Cattle. 7th ed. Natl. Acad. Sci., Washington, DC.

Orskov, E. R., D. E. Meehan, N. A. Mac Leod, and D. J. Kyle. 1999. Effect of glucose supply on fasting nitrogen excretion and effect of level and type of volatile fatty acid infusion on response to protein infusion in cattle. Br. J. Nutr. 81:389-393.

Prigge, E. C., M. J. Baker, and G. A. Varga. 1984. Comparative digestion, rumen fermentation and kinetics of forage diets by steers and wethers. J. Anim. Sci. 59:237-245.

Reynolds, C. K., H. F. Tyrrell, and P. J. Reynolds. 1991. Effects of diet forage-to-concentrate ratio and intake on energy-metabolism in growing beef heifers-Whole-body energy and nitrogen-balance and visceral heat-production. J. Nutr. 121:994-1003.
Robson, D. S. 1959. A simple method for constructing orthogonal polynomials when the independent variable is unequally spaced. Biometrics 15:187-191.

Satter, L. D., and L. L. Slyter. 1974. Effect of ammonia concentration of rumen microbial protein production in vitro. Br. J. Nutr. 32:199-208.

Schadt, I., W. H. Hoover, T. K. M. Webster, W. V. Thayne, and G. Licitra. 1999. Degradation of two protein sources at three solids retention times in continuous culture. J. Anim. Sci. 77:485491.

Smith, D. 1981. Removing and analyzing carbohydrates from plant tissue. R2107 ed. Wisconsin Agricultural Experiment Station, Madison.

SAS Institute. 2006. SAS User's Guide: Statistics. Version 9. 1. 3. SAS Inst. Inc., Cary, NC.

Tyrrell, H. F., and P. W. Moe. 1975. Effect of intake on digestive efficiency. J. Dairy Sci. 58:1151-1163.

Van Soest, P. J., J. B. Robertson, and B. A. Lewis. 1991. Methods for dietary fiber, neutral detergent fiber, and nonstarch polysaccharides in relation to animal nutrition. J. Dairy Sci 74:3583-3597.

Vanzant, E. S., R. C. Cochran, and E. C. Titgemeyer. 1998. Standardization of in situ techniques for ruminant feedstuff evaluation. J. Anim. Sci. 76:2717-2729.

Waldo, D. R., R. W. Miller, M. Okamoto, and L. A. Moore. 1965 Ruminant utilization of silage in relation to hay pellets and hay plus grain. 2. Rumen content dry matter passage and water intake. J. Dairy Sci. 48:1473-1480.

Zanton, G. I., and A. J. Heinrichs. 2005. Meta-analysis to assess effect of prepubertal average daily gain of Holstein heifers on first-lactation production. J. Dairy Sci. 88:3860-3867.

Zanton, G. I., and A. J. Heinrichs. 2007. The effects of controlled feeding of a high-forage or high-concentrate ration on heifer growth and first-lactation milk production. J. Dairy Sci 90:3388-3396.

Zanton, G. I., and A. J. Heinrichs. 2008. Analysis of nitrogen utilization and excretion in growing dairy cattle. J. Dairy Sci 91:1519-1533. 